\title{
ASSESSMENT-BASED MATERIAL DEVELOPMENT: USING STUDENTS' WORKS FOR DEVELOPING ENGLISH LEARNING MATERIAL
}

\author{
Kristiandi $^{1}$, Hefy Sulistyawati ${ }^{2}$, Dewi Cahyaningrum ${ }^{3}$ \\ Universitas Sebelas Maret, Indonesia \\ ${ }^{1}$ kris_pradipta@yahoo.com \\ 2have_i@hotmail.com \\ 3 cahyaningrum23@gmail.com
}

\begin{abstract}
Despite the vital role of teachers in delivering English instructions, English learning material takes the most prominent role in the learning process. As English learning process is expected to be learning centered, the role of English learning material becomes more strategic and crucial in fostering students' learning. With the adopted curriculum as the framework and the concept of authentic materials as the basis, the development of English learning material needs to incorporate students' learning problems and expectations. As such, teachers as learning facilitators are supposed to be alert to students' needs for learning as well as their expectations and use them to update the learning materials as learning takes place. Students' worksheets, which are the reflection of their current interlanguage, are very good resource for teachers in developing a series of updated English learning materials and relevant communicative activities which are student-friendly. Developed on the revised Communicative Language Teaching (CLT) approach and Krashen's Input Hypothesis, this paper highlights the importance of accommodating students' learning problems for developing English learning materials by using formative and summative assessments results within a period of an English instructional program.
\end{abstract}

Key words: English learning material, assessment-based material, input hypothesis

\section{INTRODUCTION}

The practice in English language pedagogy in the context of Second (and Foreign) Language Acquisition (SLA) has benefited from the social-interaction and cognitive theories on language learning and acquisition. From the view of socialinteractionists, i.e. Vygotsky, learners construct the new language through socially mediated interaction which is within their current Zone of Proximal Development (ZPD). The nativists' view following Krashen's input hypothesis, on the other hand, claims that learners subconsciously operate natural internal mechanisms upon comprehensible input (i+1). The distinction between the two mainstreams is that the former would put emphasis on nurture while the latter on nature. Notwithstanding the distinction between the two, both agree that learners need to have language exposures which will provide inputs for learning.

The aforementioned theories on SLA suggest that ESL/EFL learners are central to determining which approach to be implemented and how the learning material (input) is to be developed. The English instructions and the learning material must be tailored to meet the students' needs and ways of learning. To do this, teachers need to be well informed about English language pedagogy as well as the characteristics of the students, which include their current levels of English proficiency and their learning problems. White (1987) claims that besides the comprehensible input, the incomprehensible input also enhances SLA. The incomprehensible input, which is encountered during learning, will give learners 
feedback and the learners will then modify their inter-language rules to understand the structure. White argues that when the language input is incomprehensible because of some aspects which the language learners have not yet acquired, the language learners will draw their attention to the specific aspects to be acquired. This stance of language learning process is purely based on learners' own problems in understanding the inputs which their teachers might have thought to be comprehensible by the learners.

\section{LITERATURE REVIEW}

The importance and the role of language input based on the social-interactional and cognitive theories on SLA are fundamental bases for English as a Second Language (ESL)/English as a Foreign Language (EFL) instructions. However, the term comprehensible input is very difficult to define, yet not easy to quantify. Not to mention, the different levels of students' English proficiency have made the identification of the comprehensible inputs for ESL/EFL classrooms difficult to do. On the other hand, teachers must provide their students with language exposures which is rich in language inputs, which must be comprehensible inputs. This is what has been difficult to do given the fact that ESL/EFL learners are individuals who have different English proficiency and different needs and ways of learning English. Thus, the question is how to determine the current level of the heterogeneous students in the classroom as well as the quality and the quantity of the input to cater the different learning needs of the students.

Gass (1997) advocated that SLA cannot take place in a vacuum without considering having exposure to some sort of language inputs. In the same line, much work on research on the area of SLA has been concerned with the importance, the role, and how the linguistic inputs are processed (Doughty \& Long, 2003; Ellis, 1994; Ellis, 1997; Gass \& Selinker, 1994; Nasaji \& Fotos, 2010; Patten \& Benati, 2010; VanPatten \& Williams, 2007). Further, Ellis (2008), highlights that SLA theories attach different importance to the role of input in the language acquisition process but they all acknowledge the need for language input. In terms of language learning process by means of having exposures on linguistic inputs, Doughty \& Long (2003) put emphasis on the conceptualization of how language input is processed by language learners.

In terms of providing language inputs for language production (output), Gass and Selinker (1994) propose a five-level framework for turning input into output: apperceived input, comprehended input, intake, integration, and output which account for the SLA process. This model specifies language that input refers to various sources of second language data which the learners are exposed to. Within this framework, the data (inputs) processing in language learning process is considered to go through five stages. 


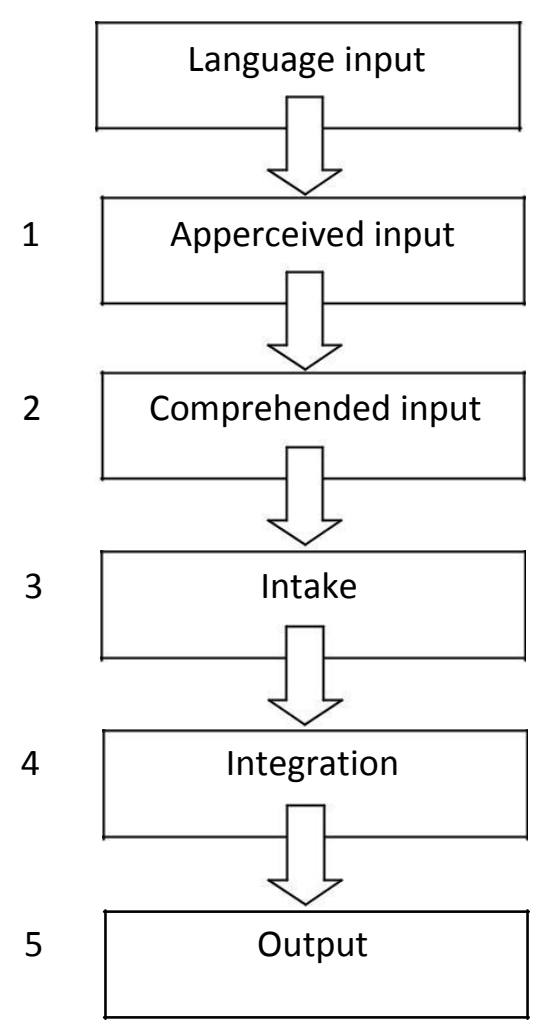

Gass and Selinker's Model (1994) for Second Language Acquisition

In the first stage, apperceived input, some of the language input is noticed by the language learner because of some specific features such as frequency, prior knowledge, affect, and attention (Gass \& Selinker, 1994). In the second stage, learners comprehend the bit of language input which is apperceived. Then, in the third stage, the comprehended language input is internalized by the language learners, which refers to intake. The fourth stage is the integration of the intake with the learners' prior knowledge. Then, they will arrive at the fifth stage, which is the output in the form of learners' written or spoken language production.

\section{DISCUSSION}

Since language input for SLA needs to be mediated through communicative activities (social interactions), the classroom communicative activities need to incorporate language exposures which are designed to provide ESL/EFL learners with comprehensible language inputs. When learners are engaged in communication using English in the classroom, they will be involved in an interaction which facilitates language learning. With the use of authentic materials, learners will be facilitated to acquire linguistic rules as well as the functions of the language expressions being learnt. In other words, ESL/EFL learners need to be facilitated with English instructions and learning materials which enable them to learn and acquire the rules and functions of English expressions. However, developing a good ESL/EFL classroom procedures and learning materials for students with different English proficiency is not an easy task to do.

Using Communicative Language Teaching (CLT) as the umbrella for communicative classroom instructions, teachers can give ESL/EFL learners opportunities to functional expressions as well as the structure of the expressions. Students will in turn acquire the language through natural communication. During 
the interaction, students will process the language input by means of internal mechanism to build their interlanguage. When students find some incomprehensible input, they will use it as a negative feedback, which will be used to revise their current understanding of the rules. This will happen as a mental process within the individual students. Teachers, on the other hand, are learning facilitators who will seek for data of their students' language learning. These data are obtained by means of authentic assessment. They will notice what their students can produce in terms of language output and what their students cannot produce. The students will also evaluate their leearning progress, especially their learning problems, which constitutes assessment as learning.

O'Malley and Pierce (1996) states that authentic assessment, which is multiple forms of assessment, must be consistent with classroom goals, curricula, and instructions. Teachers are encouraged to do authentic assessment, which includes 'assessment for learning' as for determining students' current progress for the purpose of helping them learn better, and 'assessment of learning' for measuring students' competency or learning quality based on certain criterion at the end of a learning process. In addition to the two types of assessment above, the assessment guides also mention another type of assessment, which is 'assessment as learning' for helping students monitor and evaluate their learning, teachers are also encouraged to use various assessment methods suitable for certain competency and use the result of assessment for informing their teaching, including conducting remedial teaching and enrichment program.

Assessment of student learning conducted by teachers is aimed at: (a) knowing the level of students' competency mastery; (b) determining competency mastery; (c) determining remedial and enrichment program based on the level of students' competency mastery; and (d) improving learning process. A range of assessment models, including observation of student learning progress, peer assessment, written and spoken tests, tasks, projects, language performance, can be utilized to monitor and improve student learning. These assessment models can be used for different teaching focus and purposes. Assessment of student learning includes daily assessment, mid-term assessment, and final-term assessment for assessing attitude, knowledge and skills. Teachers are also encouraged to use portfolio in the assessment process. English teachers are encouraged to develop relevant assessment procedures for collecting information on students'learning progress and learning problems, which are then to be used as the information for updating the learning material. The updated material can be used for remedial or enrichment program.

\section{CONCLUSION}

The development of English teaching-learning material must consider the local condition of the classroom. Analysis on students' learning needs, which include their learning problems, preferences and their current level of English proficiency must be the basis of material development. Students' current language production, which is their current inter-language, is rich of information that can be used as the basis for developing the next teaching-learning material. The data from students' work provide teachers with information as to what remains incomperhensible, what has been comprehended, and what has already been the students' communicative competence. English teaching-learning material must be updated during the instructional period based on the students' learning progress as well as the students' 
ways of learning by involving the students in the material developmet directly and indirectly.

\section{REFERENCES}

Doughty, C., \& Long, M. H. (2003). The handbook of second language acquisition. Blackwell publishing.

Ellis, R. (1994). The study of Second language acquisition. Oxford: Oxford University Press.

Ellis, R. (1997). Second language acquisition. Oxford: Oxford University Press.

Ellis, R. (2008). The study of Second language acquisition (second ed). Oxford: Oxford University Press.

Gass, S. M. (1997). Input, interaction, and the second language learner. Mahwah, NJ: Lawrence Elrbaum.

Gass, S., \& Selinker, L. (1994). Second language acquisition: an introductory course. Hilldale, NJ: Lawrence Erlbaum Associates.

Krashen, S. (1985). The input hypothesis. Torrance, CA: Laredo Publishing Company.

Nassaji, H., \& Fotos, S. (2011). Teaching Grammar in Second Language Classrooms: Integrating form-focused instruction in communicative context. New York: Routlege Publishing.

O'Malley, J. M., and Pierce L.V. (1996). Authentic assessment for English language learning: Practical approaches for teachers. New York: AddisonWesley Publishing.

Patten, V. B., \& Benati, A. G. (2010). Key terms in second language acquisition. Continuum international publishing group. London.

VanPatten, W, \& Williams, J. (2007). Theories in second language acquisition: An introduction. Lawrence Erlbaum Associates: New York.

White, L (1987). Against comprehensible input: The Input Hypothesis and the development of L2 competence. Applied linguistics, 8, 95-110. 